\title{
PENGARUH BUDAYA ORGANISASI TERHADAP MUTU PELAYANAN \\ PADA PUSAT PENGEMBANGAN DAN PEMBERDAYAAN PENDIDIK DAN TENAGA KEPENDIDIKAN (PPPPTK) BISNIS DAN PARIWISATA JAKARTA

\author{
Oleh: Drs. Waluyo MM \& Ismirah \\ Waluyop4tkbispar@gmail.com
}

\begin{abstract}
Abstrak
Tujuan penelitian ini adalah untuk mengetahui dan menganalisis pengaruh budaya organisasi terhadap mutu pelayanan pegawai pada Pusat Pengembangan dan Pemberdayaan Pendidik dan Tenaga Kependidikan Bisnis dan Pariwisata.

Metode penelitian yang digunakan adalah deskriptif kuantitatif yang artinya penelitian ini hanya sebatas mengungkapkan suatu permasalahan yang ada dan mencoba menemukan solusi atau pemecahan dari permasalahan yang ada. Teknik pengumpulan data dalam penelitian ini menggunakan teknik observasi dan kuesioner. Data yang diperoleh dari kuesioner dengan jumlah responden sebanyak

72 orang. Pengujian data kuesioner dianalisis dengan menggunakan analisis statitik pada program Microsoft Excel 2007 dan perhitungan manual dengan metode uji validitas dan reliabilitas, koefisien korelasi, koefisien determinasi dan uji signifikan hipotesis pada $\alpha=5 \%$.

Hasil penelitian ini menunjukkan adanya pengaruh secara positif dan signifikan antara variabel budaya organisasi terhadap mutu pelayanan pegawai pada Pusat Pengembangan dan Pemberdayaan Pendidik dan Tenaga Kependidikan Bisnis dan Pariwisata dengan diperoleh koefisien korelasi $r=0,716$. Hasil perhitungan koefisien determinasi adalah 51,265\%, yang memiliki arti bahwa mutu pelayanan pegawai pada Pusat Pengembangan dan Pemberdayaan Pendidik dan Tenaga Kependidikan Bisnis dan Pariwisata dipengaruhi oleh variabel budaya organisasi sebesar 51,265\% dan sisanya sebesar 48,735\% dipengaruhi oleh variabel lain yang tidak diteliti dalam penelitian ini. Pada uji $t$ diperoleh thitung $=8,581$ lebih besar dari tabel $=1,658$, maka dapat disimpulkan bahwa budaya organisasi berpengaruh terhadap mutu pelayanan pegawai pada Pusat Pengembangan dan Pemberdayaan Pendidik dan Tenaga Kependidikan Bisnis dan Pariwisata.
\end{abstract}

Kata kunci : Budaya Organisasi dan Mutu Pelayanan Pegawai

PENDAHULUAN

\section{Latar Belakang Masalah}

Budaya organisasi merupakan seperangkat asumsi dasar dan keyakinan yang dianut oleh anggota-anggota organisasi, kemudian dikembangkan dan diwariskan guna 
mengatasi masalah-masalah adaptasi eksternal dan masalah- masalah intergrasi internal.

Budaya organisasi merupakan pokok penyelesaian masalah-masalah eksternal dan internal yang pelaksanaanya dilakukan secara konsisten oleh suatu kelompok yang kemudian mewariskan kepada anggota baru sebagai cara yang tepat untuk memahami, memikirkan dan merasakan terhadap masalah-masalah terkait seperti di atas.

Mutu pelayanan merupakan pelayanan yang memuaskan setiap pemakai jasa pelayanan yang sesuai dengan tingkat kepuasan rata-rata sesuai dengan standar kode etik profesi. Memenuhi dan melebihi kebutuhan serta harapan pelanggan melalui peningkatan yang berkelanjutan atas seluruh proses. Secara umum mutu pelayanan adalah derajat kesempurnaan pelayanan sesuai dengan standar profesi dan standar pelayanan dengan menggunakan potensi sumber daya yang tersedia.

Kaitan erat antara budaya organisasi dan mutu pelayanan dapat dijelaskan bahwa menjadi suatu keharusan bagi organisasi untuk selalu berusaha menjaga agar pelanggan merasa puas dengan pelayanan dan produk yang diberikan. Sumber daya manusia yang berkompetensi atau memiliki mutu pelayanan kepada pelanggan merupakan kualifikasi yang wajib bagi organisasi yang memiliki perhatian besar terhadap kebutuhan pelanggannya. Pelanggan adalah pihak yang sangat penting bagi setiap organisasi. Kaitan erat tersebut dapat dikatakan bahwa semakin tinggi budaya organisasi, maka semakin tinggi pula mutu pelayanan pegawai, demikian pula sebaliknya semakin rendah budaya organisasi, maka semakin rendah pula mutu pelayanan pegawai Pusat Pengembangan dan Pemberdayaan Pendidik dan Tenaga Kependidikan (PPPPTK) Bisnis dan Pariwisata Jakarta itu sendiri.

Budaya organisasi di lingkungan kerja PPPPTK Bisnis dan Pariwisata Jakarta yang berkembang dalam suatu organisasi akan berdampak pada kualitas kinerja dari organisasi itu sendiri. Fakta lapangan yang terkait dengan budaya organisasi antara lain masih banyak pegawai yang kurang disiplin masuk kerja, kurangnya pengetahuan tentang sistem kediklatan, kurangnya kemandirian pegawai, perlunya peningkatan integritas dalam sistem kerja, kurangnya komitmen terhadap tugas dan tanggung jawab.

Kemampuan para pegawai PPPPTK Bisnis dan Pariwisata dalam memberikan pelayanan untuk mengelola diklat memang sudah selayaknya mendapatkan porsi lebih baik, karena hal ini menyangkut eksistensi dan kredibilitas PPPPTK Bisnis dan Pariwisata sebagai lembaga diklat. Hal nyata yang menunjukkan belum optimalnya memberikan mutu pelayanan kepada pelanggan pada kemampuan mengelola diklat, dapat dilihat berdasarkan hasil data survei peneliti di lapangan antara lain: persiapan dan 
pendistribusian bahan ajar belum tepat waktu, Jadwal diklat yang senantiasa terjadi perubahan dalam waktu sedang berjalan, widyaiswara/instruktur yang tidak tepat waktu, penetapan peserta diklat tidak berdasarkan pada kebutuhan, pemanggilan peserta diklat yang mendadak. Permasalahan diatas sebenarnya tidak akan pernah terjadi bilamana pegawai yang terlibat di dalam pengelolaan diklat ini memiliki budaya kerja yang tinggi, serta kreativitas berpikir yang baik. Karena bagaimanapun juga sistem yang telah dikembangkan di lembaga diklat yang telah mendapatkan sertifikat ISO seperti PPPPTK Bisnis dan Pariwisata Jakarta tentunya sudah memiliki standar baku.

Sudah banyak yang telah diperbuat oleh jajaran fungsi PPPPTK terkait didalam memberikan mutu pelayanan kepada pelanggan dengan sebaik- baiknya seperti yang telah dilaksanakan para pegawai, akan tetapi rasanya belum saatnya kita puas diri akan apa yang sudah dilakukan pada pelayanan tersebut. Seiring dengan kemajuan jaman khususnya arus informasi baik dari system dan teknologinya, hal tersebut akan membawa dampak perubahan terhadap system pelatihan. Sehingga perlu dilakukan semacam reenginering terhadap paradigma yang selama ini ada. Untuk dapat mengadakan perubahan paradigma baru tentunya yang utama adalah peningkatan pelayanan pegawai kepada pelanggan terlebih dahulu harus di tingkatkan kualitasnya.

Berdasarkan latar belakang masalah yang telah diuraikan tersebut di atas PPPPTK Bisnis dan Pariwisata Jakarta mengharapkan budaya organisasi yang dimiliki para pegawai sesuai dengan tujuan, sehingga dapat memberikan mutu pelayanan yang sebaik-baiknya kepada PPPPTK Bisnis dan Pariwisata Bojongsari Kota Depok. Berdasarkan kaitan latar belakang masalah di atas, maka penulis mengambil judul penelitian "Pengaruh Budaya Organisasi terhadap Mutu Pelayanan Pegawai" yang dilaksanakan oleh pegawai PPPPTK Bisnis dan Pariwisata Jakarta.

\section{Identifikasi Masalah}

Berdasarkan latar belakang masalah diatas, maka dalam penelitian ini dapat diidentifikasikan masalah-masalah sebagai berikut:

1. Masih banayak pegawai yang kurang disiplin diwaktu kerja

2. Rendahnya pengetahuan pegawai tentang sestem kediklatan

3. Kurangnya kemandirian pegawai

4. Persiapan dan pendistribusian bahan ajar belum tepat waktu

5. Jadwal diklat senantiasa terjadi perubahan dalam waktu berjalan

6. Pemanggilan peserta diklat yang mendadak 


\section{Pembatasan Masalah}

Sejalan dengan identifikasi masalah di atas, di ketahui berbagai permasalahan yang menjadi kompleksitas pembahasan dalam penelitian ini maka penulis membatasi masalah tersebut yang tujuan fokus terhadap analisa penelitian sehingga, berikut batasan masalah dalam penelitian ini:

1. Budaya Organisasi

Budaya organisasi merupakan seperangkat asumsi dasar dan keyakinan yang dianut oleh anggota-anggota organisasi, kemudian dikembangkan dan diwariskan guna mengatasi masalah-masalah adaptasi eksternal dan masalah-masalah intergrasi internal. Budaya organisasi merupakan pokok penyelesaian masalah-masalah eksternal dan internal yang pelaksanaanya dilakukan secara konsisten oleh suatu kelompok yang kemudian mewariskan kepada anggota baru sebagai cara yang tepat untuk memahami, pemikirkan dan merasakan terhadap masalah-masalah terkait seperti di atas.

2. Mutu Pelayanan

Yang dimaksud mutu pelayanan dalam penelitian ini merupakan pelayanan yang memuaskan setiap pemakai jasa pelayanan yang sesuai dengan tingkat kepuasan ratarata sesuai dengan standar kode etik profesi. Memenuhi dan melebihi kebutuhan serta harapan pelanggan melalui peningkatan yang berkelanjutan atas seluruh proses. Secara umum mutu pelayanan adalah derajat kesempurnaan pelayanan sesuai dengan standar profesi dan standar pelayanan dengan menggunakan potensi sumber daya yang tersedia. Secara umum mutu pelayanan adalah derajat kesempurnaan pelayanan sesuai dengan standar profesi dan standar pelayanan dengan menggunakan potensi sumber daya yang tersedia.

3. Tempat penelitian ini dilakukan pada Pusat Pengembangan dan Pemberdayaan Pendidik dan Tenaga Kependidikan (PPPPTK) Bisnis dan Pariwisata Jakarta yang beralamat di Jl. Raya Parung Km. 22-23 Bojongsari, Depok 16516 - Jawa Barat.

4. Waktu pengambilan data dilakukan selama 3 bulan dimulai sejak bulan Januari 2016 sampai dengan Maret 2016.

\section{Perumusan Masalah}

Untuk mencegah kerancuan dalam pembatasan masalah maka dapat dirumuskan masalah: 
1. Bagaimana budaya organisasi pegawai pada PPPPTK Bisnis dan Pariwisata Jakarta

2. Bagaimana mutu pelayanan pegawai pada PPPPTK Bisnis dan Pariwisata Jakarta?

3. Seberapa besar pengaruh budaya organisasi terhadap mutu pelayanan pegawai pada PPPPTK Bisnis dan Pariwisata Jakarta?

\section{Kerangka Berpikir}

Berdasarkan latar belakang dan rumusan masalah terkait pembinaan pegawai, bahwa mutu pelayanan (Y) diasumsikan dapat ditingkatkan apabila budaya organisasi dapat dioptimalkan. Untuk lebih jelasnya dapat dilihat pada gambar kerangka pemikiran berikut:

\begin{tabular}{|ll|}
\hline \multicolumn{1}{|c|}{$\begin{array}{l}\text { Budaya Organisasi } \\
\text { Variabel X }\end{array}$} \\
\hline \multicolumn{1}{|c|}{ Indikator } \\
\hline 1. & Inovasi dan pengambilan \\
resiko \\
2. \\
3. Orientian pada hal detail \\
4. Agresivitas \\
5. Stabilitas
\end{tabular}

Sumber: Wibowo (2013:37)

\begin{tabular}{|ll|}
\hline \multicolumn{1}{|c|}{$\begin{array}{l}\text { Mutu Pelayanan } \\
\text { Variabel Y }\end{array}$} \\
\hline \multicolumn{1}{|c|}{ Indikator } \\
\hline 1. Berwujud \\
2. Kehandalan \\
3. Pengetahuan dan \\
keterampilan \\
4. Kemudahan hubungan \\
5. Kebutuhan masyarakat \\
\hline Sumber: Sedarmayanti (2004:35)
\end{tabular}

\section{Gambar 1.1 Kerangka Berpikir}

\section{Hipotesis}

Setelah dilakukan kajian teoritis pada kerangka berpikir diatas, maka dapat di ambil kesimpulan sementara sebagai berikut:

$\mathrm{H} 1=$ diduga terdapat pengaruh budaya organisasi terhadap mutu pelayanan pegawai.

Selain hipotesis penelitian juga dapat diajukan hipotesis statistik sbb:

H01 : $\beta=0=$ Tidak terdapat pengaruh budaya organisasi terhadap mutu pelayanan

Pegawai.

\section{LANDASAN TEORI}

\section{Pengertian Manajemen}




\section{Pengertian}

manajemen berasal dari kata to manage yang berarti mengatur. Manajemen juga bisa menganalisa dan menetapkan tujuan-tujuan serta mendeterminasi tugas-tugas dan kewajiban-kewajiban secara baik, efektif dan efisien. Manajemen mempunyai beberapa pengertian dan definisi yang berbeda-beda, diantara para ahli manajemen. Hal ini disebabkan oleh sudut pandang yang berbeda-beda diantara para ahli itu sendiri. Manajemen merupakan suatu proses yang khas terdiri dari tindakan- tindakan perencanaan, pengorganisasian, penggerakan dan pengendalian yang di lakukan untuk menentukan serta mencapai sasaran-sasaran yang telah di tentukan melalui pemanfaatan sumber daya manusia dan sumber daya lainnya. (Hasibuan, 2005:3).

Manajemen harus memberikan arahan kepada lembaga yang di kelolanya, ia harus memikirkan secara tuntas misi dari lembaga itu, menetapkan sasaran-sasaran dan mengorganisasikan sumber daya untuk tujuan yang telah digariskan oleh lembaga atau perusahaan. Sesungguhnya manajemen bertanggung jawab terhadap pengarahan visi serta sumber daya ke jurusan hasil-hasil yang paling besar dan efisien. (Hasibuan, 2005:5).

Manajemen di definisikan oleh Sondang P. Siagian, sebagai "kemampuan atau keterampilan untuk memperoleh suatu hasil dalam rangka pencapaian tujuan melalui kegiatan-kegiatan orang lain.” (Siagian, 2002:5).

Seperti yang telah dikemukakan di atas dapat di simpulkan bahwa manajemen merupakan ilmu dan seni, serta di dalamnya terdapat proses yang sistematis. Manajemen sebagai ilmu pengetahuan (management as a science), manajemen adalah suatu ilmu yang bersifat inter-disipliner dengan menggunakan bantuan-bantuan, ilmu-ilmu sosial, filsafat dan matematika. Manajemen sebagai seni (managenent as an art), manajemen adalah seni mengatur proses pemanfaatan sumber daya manusia dan sumber-sumber lainnya secara efektif untuk mencapai tujuan tertentu.

\section{Pengertian Manajemen Sumber Daya Manusia}

Semula SDM Merupakan terjemahan dari Human Resaures namun ada pula ahli yang menyamakan sumber daya manusia dengan Manpower (tenaga kerja), sedangkan sebagi orang menyatakan pengertian sumber daya manusia dengan personal (Personalia, kepegawaian, dan sebagainya).

Menurut Dessler (2000:201) manajemen personalia disamakan dengan fungsifungsi manajemen khususnya staffing, yaitu penetapan jenis pegawai yang perlu 
diangkat, perekrutan calon pegawai, penyusunan prestasi hubungan kerja pegawai. Manajemen personalian merupakan bagian dari manajemen yang merupakan ruang lingkup pada aktifitas yang berhubungan dengan tenaga kerja. Manajemen personalia adalah penarikan, seleksi, pengembangan, penggunaan dan pemeliharaan sumber daya manusia $u$ mencapai baik tujuan-tunuan individu maupun organisasi. Samsudin (2009:22) menyatakan bahwa manajemen sumber daya manusia adalah suatu kegiatan pengelolaan yang meliputi pendayagunaan, pengembangan, penilaian, pemberian balas jasa bagi manusia sebagai individu anggota organisasi atau perusahaan bisnis. manajemen sumber daya manusia juga menyangkut cara-cara mendesain sistem perencana, penyusunan karyawan, pengelolaan karyawan, evaluasi kinerja, kompensasi karyawan, dan hubungan ketenagakerjaan. Manajemen sumber daya manusia melibatkan semua praktik manajemen yang dapat mempengaruhi secara langsung terhadap organisasi.

Manajemen Sumber Daya Manusia (MSDM) merupakan bidang strategis dari organisasi. Manajemen sumber daya manusia harus dipandang sebagai perluasan dari pandangan tradisonal untuk mengelola orang secara efektif dan untuk itu membutuhkan pengetahuan tentang perilaku manusia dan kemampuan mengelolanya.

Menurut Sutrisno (2009:1) Sumber Daya Manusia merupakan satu- satunya sumber daya yang memiliki akal perasaan, keinginan, keterampilan, pengetahuan, dorongan, daya dan karya (rasio, rasa dan karsa). Semua potensi SDM tersebut berpengaruh terhadap upaya organisasi dalam mencapai tujuan. Betapapun majunya teknologi, perkembangan, informasi, tersedianya modal dan memadainya bahan,jika tanpa SDM sulit bagi organisasi itu untuk mencapai tujuannya.

Menurut Simamora (2006:4) Manajemen merupakan proses pendayagunaan bahan baku dan sumber daya manusia untuk mencapai tujuan yang ditetapkan.

Proses ini melibatkan organisasi, arahan, koordinasi, dan evaluasi orang-orang guna mencapai tujuan tersebut. Esensi manajemen adalah aktivitas bekerja melalui orang lain untuk meraih berbagai hasil. Melalui manajemen dilakukan proses pengintegrasian berbagai sumber daya dan tugas untuk mencapai berbagai tujuan organisasi.

Menurut Hasibuan (2009:10) manajemen sumber daya manusia adalah ilmu dan seni mengatur hubungan dan peranan tenaga kerja agar efektif dan efisien membantu terwujudnya tujuan organisasi, pegawai dan masyarakat. Tujuannya agar organisasi mendapatkan kepuasan dari pekerjaannya dalam bentuk efektifitas dan 
efisiensi dari biaya yang dikeluarkan.

Menurut Follet dalam Sule (2010:5) menyatakan bahwa manajemen sumber daya manusia adalah seni dalam menyelesaikan sesuatu melalui orang lain". Dalam pemgertian ini sedikitnya mengandung tiga faktor yaitu adanya penggunaan sumber daya organisasi berupa sumberdaya manusia dan sumber-sumber produksi lainya, adanya proses yang bertahap dari mulai perencanan, pengorganisasian, pengarahan dan pengimplementasian hingga pengendalian dan pengawsan, serta adanya seni dalam menyelesaikan pekerjaan tersebut.

Suwarto (2014:3) menyatakan bahwa manajemen sumber daya manusia adalah suatu proses yang berkesinambungan dari mengidentifikasi, pengukuran, dan pengembangan sumber daya manusia baik secara perorangan, kelompok, dan organisasi serta pelurusan kerja sesuai dengan tujuan strategis organisasi. Manajemen berkelanjutan mencakup proses perancangan maksuda dan tujuan yang tidak pernah berakhir, proses pengamatan kerja, proses untuk memberi dan menerima pelatiahan yang terus berkelanjutan serta memberikan atau menerima umpan balik. Pihak manajer meminta agar para pegawai memastikan bahwa output dan aktivitas sejalan dengan tujuan strategis organisasi, sehingga akan dapat membantu organisasi untuk mendapatkan keuntungan yang kompetitif.

\section{Budaya Organisasi}

Secara etimologi, budaya organisasi terdiri dari dua kata, yaitu budaya dan organisasi. Organisasi merupakan suatu sistem yang mantap dari sekumpulan orang yang bekerja sama untuk mencapai tujuan bersama, melalui suatu jenjang kepangkatan dan pembagian. Sedangkan pengertian budaya adalah suatu set nilai, penuntun kepercayaan akan suatu hal, pengertian dan cara berpikir yang dipertemukan oleh para anggota organisasi dan diterima oleh anggota baru. Budaya organisasi merupakan penerapan nilai-nilai dalam suatu masyarakat yang terkait, bekerja di bawah naungan suatu organisasi. Secara Terminologi budaya organisasi adalah sebuah sistem makna bersama yang dianut oleh para anggota yang membedakan suatu organisasi dari organisasi-organisasi lainnya. Sistem makna bersama ini adalah sekumpulan karakteristik kunci yang dijunjung tinggi oleh organisasi. Menurut Heri (2013:1) budaya organisasi adalah sebuah sistem makna bersama yang dianut para anggota yang membedakan suatu organissi dari organisasi lainya. Sistem makna bersama ini merupakan sekumpulan karakteristik kunci yang dijunjung tinggi oleh 
organissi tersebut. Budaya orgaisasi berkaitan dengan bagaimana pegawai memahami karakteristik budaya suatu organisasi, dan tidak terkait dengan apakah pegawai meyukai karakteristik itu atau tidak. Budaya organissi merupakan suatu sikap deskriptif, bukan seperti kepuasan kerja yang lebih bersifat evaluatif. Menurut Koentjaraningrat dalam Umam (2010:128) budaya organisasi adalah seperangkat asumsi dasar dan keyakinan yang dianut oleh angota- angota organisai, kemudian dikembangkan dan diwariskan guna mengatasi masalah-masalah adaptasi eksternal dan masalah-masalah intergrasi internal. Budaya organisasi merupakan pokok penyelesaian masalah-masalah eksternal dan internal yang pelaksanaanya dilakukan secara konsisten oleh suatu kelompok yang kemudian mewariskan kepada anggota baru sebagai cara yang tepat untuk memahami, pemikirkan dan merasakan terhadap masalah- masalah terkait seperti diatas.

Menurut Lodge (2014:4) budaya organisasi adalah suatu sistem penyebaran keyakinan dan nilai-nilai yang dikembangkan di dalam suatu organisasi sebagai pedoman perilaku anggotanya. Budaya organisasi merupakan suatu kepercayaan dan nilai-nilai yang menjadi falsafah utama yang dipegang teguh oleh anggota organisasi dalam menjalankan atau mengoperasionalkan kegiatan organisasi. Budaya organisasi sering kali menggambarkan dalam arti yang dimiliki bersama. Pola-pola kepercayaan, simbol-simbol yang berkembang dari waktu ke waktu dan fungsi sebagai perekat yang menyatukan organisasi tersebut.

Menurut Hunt dalam Suharnan (2005:283) masalah adalah suatu kesenjangan antara situasi sekarang dengan situasi yang akan datang atau tujuan yang diinginkan. Jadi suatu masalah muncul apabila ada halangan atau hambatan yang memisahkan antara present state dengan goal state.

Menurut Amstrong dalam Chatab (2007:10) budaya organisasi adalah pola nilai, norma, keyakinan, sikap dan asumsi yang bisa sudah tidak diartikulasikan, namun membentuk dan menentukan cara orang berkelakuan dan menyelesaikan sesuatu. budaya organisasi merupakan keyakinan, tata nilai dan persepsi umum yang dianut secara luas dalam membentuk dan memberi arti kepada perilaku pegawai, sehingga menjadi kebiasaan yang relatif sulit diubah. Budaya organisasi merupakan suatu sistem dari makna/arti bersama yang dianut oleh para anggotanya yang membedakan organisasi dari organisasi lainnya. Budaya organisasi adalah produk dari semua karakteristik organisasi, para anggotanya, kesuksesannya dan kegagalannya.

Menurut Boardman (2004:132) budaya organisasi dapat dilihat dari bagaimana 
cara pemimpin membimbing dan mengarahkan bawahannya. Makna lain yang terkandung dalam budaya organisasi adalah adanya pola komunikasi yang dilakukan secara terbuka, baik dari pihak pemimpin maupun pegawai. Komunikasi yang dilakukan secara terbuka akan menjamin kelancaran hubungan informasi dalam organisasi tersebut.

Goldstein dalam Soetopo (2010:123) budaya organisasi totalitas pola perilaku dan karakteristik pemikiran dari pegawai suatu organisasi. Budaya organisasi sebagai suatu ekspresi kombinasi pengaruh dari keyakinan dasar organisasi, nilai-nilai, harapan dan pola tindakantertentu. Budaya organisasi yang terbentuk dari jalinan interaksi unsur-unsur tersebut, akhirnya akan merupakan suatu kekuasaan yang tidak terlihat yang mempengaruhi pemikiran, pembicaraan maupun tindakan manusia yang organisasi dalam organisasi. Oleh sebab itu budaya organisasi perusahaan merupakan pengaruh perilaku pegawai untuk tercapainya tujuan organisasi seperti yang telah ditentukan sebelumnya.

Menurut Schein dalam Munandar (2004:262) budaya organisasiterdiri dari asumsi dasar yang dipelajari baik sebagai hasil memecah masalah yang timbul dalam proses penyesuaian dengan lingkungannya, maupun sebagai hasi pemecahan masalah yang timbul dari dalam prganisasi, antar unit-init organisasi yang berkaitan dengan integrasi. Budaya timbul sebagai hasil belajar bersama dari para anggota organisasi agar dapat tetap bertahan.

Menurut Suwarto (2009:4) budaya organisasi adalah inovasi dan pengambilan resiko, perhatian kerincian, orientasi hasil, Orientasi orang, orientasi tim, keagresifan, dan kemantapan. Organisasi diartikan sebagai, kegiatan yang membutuhkan berbagai persyaratan kemampuan dan untuk itu biasanya bagi pelakunya mendapatkan balas jasa dan kepuasan. Budaya organisasi berhubungan dengan persepsi pegawai terhadap karakteristik budaya suatu organisasi. Artinya budaya itu merupakan hal penting sebab dapat membedakan konsep organisasi dengan konsep kepuasan kerja.

Menurut Loffter dalam Sudarmanto (2009:121) apapun terminologi yang dipakai, pada prinsipnya bagi setiap organisasi mutu pelayanan kepada pelanggan, masyarakat atau pengguna layanan merupakan faktor kunci untuk menuju keberhasilan. Ketidakmampuan organisasi memahami kebutuhan dan keinginan pelanggan/masyarakat akan berakibat fatal terhadap keberlangsungan organisasi tersebut. Mutu pelayanan kepada pelanggan merupakan salah satu kompetensi yang sangat vital bagi setiap organisasi untuk membangun kepuasan pelanggan. Pelayanan merupakan setiap 
tindakan atau perbuatan yang dapat ditawarkan oleh suatu pihak kepada pihak lain.dalam era kompetisi semakin banyak pilihan penyedia produk dan pelayanan, memenuhi kebutuhan dan kepuasan pelanggan akan menjadi penentu kesuksesan organisasi dalam berkompetisi. mudah kepada masyarakat dan wajar tanpa pilih kasih yang dikarenakan memilki kedekatan dengan yang melayani dan lain sebagainya.

Menurut Moenir (2014:3) faktor-faktor pendukung dalam meningkatkan mutu pelayanan antara lain faktor kesadaran dari pimpinan dan pegawai yang berada dalam bagian pelayanan tersebut, faktor aturan yang menjadi landasan dalam pekerjaan, faktor organisasi yang merupakan alat serta sistem yang mungkin berjalannya mekanisme kegiatan pelayanan, faktor keterampilan pegawai, faktor sarana dan prasarana dalam pelaksanaan tugas, dan faktor pendapatan pegawai.

Menurut Valarie (2014:2) tujuan pelayanan antara lain menentukan pelayanan yang tersedia, memperlakukan pengguna pelayanan sebagai customer, berusaha memuaskan pengguna pelayanan sesuai yang diinginkan mereka, mencari penyampaian pelayanan yang paling baik dan berkualitas, menyediakan cara-cara bila pengguna pelayanan tidak ada pilihan lain.

\section{Pengaruh Budaya Organisasi terhadap Mutu Pelayanan}

Budaya organisasi merupakan seperangkat asumsi dasar dan keyakinan yang dianut oleh anggota-anggota organisasi, kemudian dikembangkan dan diwariskan guna mengatasi masalah-masalah adaptasi eksternal dan masalah-masalah intergrasi internal. Untuk dapat memberikan mutu pelayanan yang berkualitas maka seorang pegawai harus mempunyai budaya organisasi yang baik didalam dirinya yang akan berpengaruh terhadap sikap dan perilakunya sehingga meningkatkan mutu pelayanannya.

Dari beberapa penjelasan para ahli yang sebelumnya telah dibahas maka dapat penulis simpulkan bahwa budaya organisasi pegawai dapat mempengaruhi mutu pelayanan pegawai karena dengan memiliki budaya organisasi yang baik maka seorang pegawai akan melaksanakan tugas atau pekerjaan dengan efektif sehingga mutu pelayanannya akan meningkat serta akan berdampak pula pada tujuan perusahaan yang dapat dicapai secara optimal.

\section{METODOLOGI PENELITIAN}

\section{Ruang Lingkup Penelitian}


1. Tempat Penelitian

Penelitian ini dilaksanakan di lingkungan PPPPTK Bisnis dan Pariwisata Jalan Raya Parung Km. 22-23 Bojongsari Kota Depok Tahun 2016.

\section{Waktu Penelitian}

Penelitian dilaksanakan selama empat bulan, yaitu dari bulan Januari sampai April 2016 yang dilakukan secara bertahap dan di mulai dari prasurvei penelitian, pengajuan judul penelitian, melakukan kajian pustaka yang sesuai dengan variabel yang dipilih, menyusun proposal, seminar proposal, perbaikan proposal, membuat instrumen penelitian, uji coba instrumen, analisis validitas dan reliabilitas instrumen, pengumpulan data, analisis data, penyusunan skripsi lengkap.

\section{Metode Penelitian Sampel}

\section{Populasi}

Menurut Sugiyono (2012:61) bahwa "populasi adalah wilayah generasi yang terdiri atas obyek atau subyek yang mempunyai kualitas dan karakteristik tertentu yang ditentukan atau ditetapkan oleh penelitian untuk dipelajari dan kemudian ditarik kesimpulan".

Secara umum populasi diartikan sebagai seluruh anggota kelopmpok yang sudah ditentukan karakteristiknya dengan jelas, baik itu kelompok orang obyek atau kejadian. Populasi dalam penelitian ini adalah karyawan pada Pusat Pengembangan dan Pemberdayaan Pendidik dan Tenaga Kependidikan Bisnis dan Pariwisata (PPPPTK BISPAR) dengan ukuran populasi sejumlah 253 karyawan.

\section{Sampel}

Sampel menurut Sugiyono (2012:62) adalah "sebagian dari jumlah dan karakteristik yang dimiliki populasi". Sampel merupakan bagian dari populasi yang menjadi sumber data yang sebenarnya dalam penelitian.

Teknik pengambilan sampel pada penelitian ini adalah dengan menggunakan simple random sampling dikatakan simple (sederhana) karena pengambilan anggota sampel dari populasi yang dilakukan secara acak tanpa memperhatikan strata yang ada dalam populasi.

Dalam rangka efisiensi dan efektifitas juga berdasarkan pada keterbatasanketerbatasan baik dari segi dana, daya maupun keterbatasan waktu, maka 
penelitian ini dilakukan terhadap sampel penelitian.

Sehubungan jumlah populasinya besar dan sudah diketahui tingkat kesalahan yang dapat diambil antara 5\%-10\%, 10\%-15\% atau 20\%-25\% atau lebih. Dalam hal ini penulis menentukan dengan menggunakan rumus dari ${ }^{2}$ Taro Yaname atau Slovin dalam Bambang Suwarno (2005:245), yaitu :

$$
\frac{N}{\mathrm{n}=\mathrm{N}(e)^{2}}
$$

n : Jumlah Sampel

$\mathrm{N}$ : Jumlah populasi

e : Persentase dengan tingkat kesalahan

$$
\begin{aligned}
& \mathrm{n}=\frac{253}{1+253(10 \%)^{2}} \\
& \mathrm{n} \equiv \frac{253}{1+253(0,01)} \\
& \mathrm{n} \equiv \frac{253}{1+2,53} \\
& \mathrm{n} \equiv 253
\end{aligned}
$$$$
3,53
$$$$
n=71,671388
$$

Dari hasil di atas maka dibulatkan menjadi 72 sampel.

\section{Metode Pengumpulan data}

Sumber data yang digunakan adalah data sekunder yang dikumpulkan melalui studi dokumentasi dan literatur lainnya. Untuk mendukung kelengkapan data sekunder dilakukan kegiatan:

\section{Obsevasi}

Observasi merupakan pengamatan langsung suatu kegiatan yang sedang dilakukan, observasi sebagai teknik pengumpulan data mempunyai ciri spesifik bila dibandingkan dengan teknik yang lain, yaitu kuesioner karena observasi tidak 
terbatas pada orang tetapi juga objek-objek alam yang lain. Pengamatan ini dilakukan secara langsung terhadap perusahaan yaitu pada Pusat Pengembangan dan Pemberdayaan Pendidik dan Tenaga Kependidikan Bisnis dan Periwisata (PPPPTK BISPAR) sebagai objek penelitian terutama yang berkaitan dengan Pengaruh Budaya Organisasi Terhadap Mutu Pelayanan Pegawai.

\section{Kuesioner}

Menurut Bungin (2006:122) "Kuesioner merupakan serangkaian pertanyaan yang tersusun secara sistematis, kemudian dikirim untuk di isi oleh responden". Bentuk koesioner mengacu kepada skala Likert dalam rangka mengukur pendapat, sikap dan persepsi responden terkait dengan fenomena sosial. Menurut Sugiyono (2011:93) "skala likert digunakan untuk mengukur sikap, pendapat dan persepsi seseorang atau sekelompok orang tentang fenomena sosial”. Jawaban dari setiap instrumen mengacu pada skala likert sebagai berikut :
a. Untuk jawaban "SL" (Selalu) diberi skor 5.
b. Untuk jawaban "SR" (Sering) diberi skor 4.
c. Untuk jawaban "KK" (Kadang-Kadang) diberi skor 3
d. Untuk jawaban “JR" (Jarang) diberi skor 2.
e. Untuk jawaban “TP” (Tidak Pernah) diberi skor 1.

\section{Dokumentasi}

Data yang diperoleh melalui referensi buku, internet, penelitian terdahulu dan dokumen sejarah organisasi (lembaga).

\section{Metode Analisis}

Dari aspek metodologis, penelitian ini dilakukan dengan menggunakan metode deskriptif analisis dengan pendekatan kuantitatif. Metode ini disebut kuantitatif karena data penelitian berupa angka-angka dan analisis menggunakan statistik. Dalam rangka analisis data penelitian ini, ditempuh pendekatan atau metodologi sebagai berikut:

\section{Uji Validitas}

Uji validitas dilakukan untuk menguji apakah kuesioner yang disampaikan kepada responden valid atau tidak. Uji validitas angket dilakukan dengan mengambil 72 sampel. Metode uji validitas dan reliabilitas ini menggunakan rumus: 
Dimana:

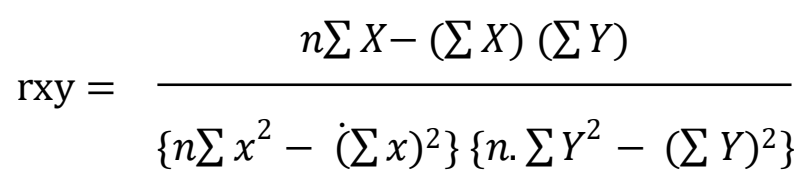

$\begin{array}{ll}\text { rxy } & \text { : koefisien korelasi } \\ \mathrm{n} & \text { : jumlah responden } \\ \mathrm{X} & \text { : variabel bebas (Budaya Organisasi) } \\ \mathrm{Y} & \text { : variabel terikat (Mutu Pelayanan) } \\ \mathrm{X}^{2} & \text { : jumlah kuadrat seluruh skor } \mathrm{X} \\ \mathrm{Y}^{2} & \text { : jumlah kuadrat seluruh skor } \mathrm{Y}\end{array}$

Dengan ketentuan penilaian uji validasinya adalah :

a. Apabila $\mathrm{r}$ hitung $>\mathrm{r}$ table (pada taraf signifikan 5\%) maka dapat dikatakan valid.

b. Apabila $\mathrm{r}$ hitung $<\mathrm{r}$ table (pada taraf signifikan 5\%) maka dapat dikatakan tidak valid.

\section{Uji Reliabilitas}

Uji Reliabilitas dilakukan terhadap instrumen Lingkungan kerja dan Kinerja karyawan dengan menggunakan metode Cronbach Alpha.

Metode Cronbach Alpha, $r_{c a}$ Metode ini dikemukakan oleh Cronbach, menganalisis reliabilitas internal alat ukur dari satu kali pengukuran. Adapun rumus yang digunakan untuk mencari nilai reliabilitas adalah rumus Cronbach Alpha (Sugiyono 2012:365) :

$$
\begin{aligned}
& \mathrm{r}^{11}=\frac{\mathrm{n}}{\mathrm{n}-1}\left[\begin{array}{c}
\mathrm{S}_{\mathrm{t}}^{2}-\sum_{\mathrm{t}-1}{ }_{\mathrm{i}} \\
\mathrm{S}^{2 \mathrm{t}}
\end{array}\right] \\
& \text { Dimana : } \quad \mathrm{r}^{11 \quad}=\text { reliabilitas instrumen } \\
& \mathrm{n}^{\mathrm{n} \mathrm{S}_{\mathrm{i}}^{2} \quad} \quad=\text { jumyaknya butir pertanyaan atau soal }
\end{aligned}
$$




$$
\mathrm{S}_{\mathrm{t}}{ }^{2}=\text { varian total }
$$

Suatu kuesioner dinyatakan reliabel apabila nilai $\mathrm{r}_{\text {hitung }}$ lebih besar daripada nilai $\mathrm{r}_{\text {tabel }}$ dengan taraf signifikan $5 \%$.

\section{Koefisien Korelasi}

Korelasi menurut Sugiyono (2012:224) adalah "angka yang menunjukkan arah dan kuatnya hubungan antara dua variabel atau lebih. Arah dinyatakan dalam bentuk hubungan positif atau negatif, sedangkan kuatnya hubungan dinyatakan dalam besarnya koefisien korelasi”. Analisis korelasi berguna untuk menentukan suatu besaran yang menyatakan bagaimana kuat hubungan suatu variabel dengan variabel lain. Rumus yang digunakan adalah:

$$
\begin{aligned}
& \mathrm{r}=\frac{n \sum x y-\left(\sum x\right)\left(\sum y\right)}{\sqrt{\left[n \sum x^{2}-\left(\sum x\right)^{2}\right]\left[n \sum y^{2}-\left(\sum y\right)^{2}\right]}} \\
& \text { Dimana : } \mathrm{r}=\text { korelasi } \\
& \mathrm{X}=\text { variabel independen } \\
& \mathrm{Y} \quad=\text { variabel dependen } \\
& \mathrm{n} \quad=\text { jumlah sampel } \\
& \sum \mathrm{X}^{2}=\text { jumlah kuadrat seluruh skor } \mathrm{X} \\
& \sum \mathrm{Y}^{2}=\text { jumlah kuadrat seluruh skor } \mathrm{Y}
\end{aligned}
$$

Tabel 3.1

Pedoman Untuk Memberikan Interpretasi Koefisien Korelasi

\begin{tabular}{|c|c|}
\hline Interval koefisien & Tingkat hubungan \\
\hline $\mathbf{0 , 0 0}-\mathbf{0 . 1 9 9}$ & Sangat rendah \\
\hline $\mathbf{0 , 2 0}-\mathbf{0 , 3 9 9}$ & Rendah \\
\hline
\end{tabular}

\begin{tabular}{|c|c|}
\hline $\mathbf{0 , 4 0}-\mathbf{0 , 5 9 9}$ & Sedang \\
\hline $\mathbf{0 , 6 0}-\mathbf{0 , 7 9 9}$ & Kuat \\
\hline $\mathbf{0 , 8 0}-\mathbf{1 , 0 0 0}$ & Sangat kuat \\
\hline
\end{tabular}

Sumber: (Sugiyono 2012:231) 


\section{Koefisien Determinasi $\left(\mathbf{R}^{2}\right)$}

Koefisien determinasi $\left(\mathrm{R}^{2}\right)$ pada intinya mengukur seberapa jauh kemampuan model dalam menerangkan variasi variabel dependen. Nilai koefisien determinasi adalah antara nol dan satu. Nilai $\mathrm{R}^{2}$ yang kecil berarti kemampuan variabel-variabel independen dalam menjelaskan variasi variabel dependen amat terbatas. Nilai yang mendekati satu berarti variabel-variabel independen memberikan hampir semua informasi yang dibutuhkan untuk memprediksi variasi variabel dependen.

Untuk mengetahui seberapa besarkah variabel bebas berpengaruh dengan variabel terikat, perlu diketahui nilai koefisien determinasi $\mathrm{R}^{2}$ karena variabel bebas yang diukur terdiri dari nilai rasio absolute dan nilai perbandingan, kegunaan dari $\mathrm{R}^{2}$ adalah untuk mengukur besarnya persentase dari variabel bebas terhadap variabel terikat dengan menggunakan rumus :

$$
\begin{aligned}
& \mathrm{R}^{2}=\mathrm{r}^{2} \times 100 \% \\
& \text { Dimana : } \mathrm{R}^{2}=\text { koefisien determinasi } \\
& \mathrm{r} \quad=\text { korelasi parsial }
\end{aligned}
$$

\section{Uji Signifikan}

Statistik uji yang digunakan adalah uji t, yaitu untuk mengetahui "Pengaruh Budaya Organisasi terhadap Mutu Pelayanan" dengan keputusan uji adalah menggunakan uji parsial dengan rumus :

$$
\begin{aligned}
& \mathrm{t}=\frac{\sqrt{n-2}}{{\sqrt{1-r^{2}}}^{2}} \\
& \text { Dimana : } \quad=\text { nilai korelasi } \\
& n \quad=\text { jumlah sampel }
\end{aligned}
$$

Hasil uji signifikan parameter individual (uji statistik t) digunakan untuk mengetahui apakah variabel independen yang terdapat dalam persamaan regresi secara individual berpengaruh terhadap nilai variabel dependen, dengan $\alpha=5 \%$ (Sugiyono 2011:184). Kriteria pengujian berdasarkan probabilitas sebagai berikut:

- Jika $\mathbf{t}_{\text {hitung }}>\mathbf{t}_{\text {tabel }}$ maka $\mathbf{H}_{\mathbf{o}}$ ditolak ada pengaruh signifikan. 
- Jika $\mathbf{t}_{\text {hitung }}<\mathbf{t}_{\text {tabel }}$ maka $\mathbf{H}_{\mathbf{0}}$ diterima tidak ada pengaruh.

\section{Operasional Variabel Penelitian}

Variabel menurut Sugiyono (2012:2) adalah segala sesuatu yang berbentuk apa saja yang di tetapkan oleh peneliti untuk dipelajari sehingga diperoleh informasi tentang hal tersebut, kemudian ditarik kesimpulannya.

Operasionalisasi variabel diperlukan untuk menentukan indikator, ukuran serta skala dari variabel-variabel yang terkait dalam penelitian, sehingga pengujian hipotesis dengan alat bantu statistik dapat dilakukan secara benar sesuai dengan judul penelitian.

Di dalam operasionalisasi konsep dalam penelitian, yang perlu dilakukan adalah menentukan faktor-faktor atau keadaan-keadaan yang dicakup dalam konsep penelitian ini. Konsep-konsep yang akan dioperasionalkan adalah sebagai berikut :

\section{Budaya Organisasi $(\mathrm{X})$}

Variabel bebas dalam penelitian ini adalah Budaya Organisasi. Budaya organisasi merupakan seperangkat asumsi dasar dan keyakinan yang dianut oleh anggotaanggota organisasi, kemudian dikembangkan dan diwariskan guna mengatasi masalah-masalah adaptasi eksternal dan masalah-masalah intergrasi internal. Indikator Budaya Organisasi (X) antara lain:
a. Inovasi
b. Perhatian pada hal detail
c. Orientasi pada orang
d. Agresivitas
e. Stabilitas

\section{Mutu Pelayanan (Y)}

Mutu pelayanan merupakan pelayanan yang memuaskan setiap pemakai jasa pelayanan yang sesuai dengan tingkat kepuasan rata-rata sesuai dengan sstandar kode etik profesi. Indikator Mutu Pelayanan (Y) antara lain:
a. Berwujud
b. Kehandalan
c. Pengetahuan dan ketrampilan
d. Kemudahan hubungan 
e. Kebutuhan masyarakat

Agar penyusunan instrumen lebih sistematis, sehingga mudah untuk dikontrol, dikoreksi dan dikonsultasikan, maka perlu dibuat kisi-kisi instrumen. Berikut ini instrumen yang diperlukan untuk mengungkapkan variabel Budaya Organisasi dan Mutu Pelayanan: 


\begin{tabular}{|c|c|c|c|}
\hline Variable Penelitian & Indikator & No & Skala \\
\hline Budaya Organisasi & $\begin{array}{l}\text { 1. Inovasi } \\
\text { 2. Perhatian pada hal detail } \\
\text { 3. Orientasi pada orang } \\
\text { 4. Agresivitas } \\
\text { 5. Stabilitas }\end{array}$ & $\begin{array}{l}2 \\
1,8 \\
7 \\
4,5 \\
6\end{array}$ & \multirow[t]{2}{*}{ Likert } \\
\hline Mutu Pelayanan & $\begin{array}{l}\text { 1. Berwujud } \\
\text { 2. Kehandalan } \\
\text { 3. Pengetahuan dan } \\
\text { Ketrampilan } \\
\text { 4. Kemudahan hubungan } \\
\text { 5. Kebutuhan masyarakat }\end{array}$ & $\begin{array}{l}1,10 \\
4,7 \\
6,9 \\
2,8 \\
3,5\end{array}$ & \\
\hline
\end{tabular}

Tabel 3.2 Kisi-kisi Instrumen

\section{PENUTUP}

\section{Kesimpulan}

Berdasarkan hasil penelitian dan pembahasan yang telah dilakukan peneliti tentang "Pengaruh Budaya Organisasi Terhadap Mutu Pelayanan Studi Kasus Pada Pusat Pengembangan dan Pemberdayaan Pendidik dan Tenaga Kependidikan (PPPPTK) Bisnis dan Pariwisata”, maka peneliti dapat mengambil kesimpulan sebagai berikut :

1. Budaya Organisasi pada Pusat Pengembangan dan Pemberdayaan Pendidik dan Tenaga Kependidikan (PPPPTK) Bisnis dan Pariwisata bisa dikatakan baik, dapat dilihat dari hasil kuesioner yang dibagikan kepada karyawan meliputi inovasi, perhatian pada hal detail, orientasi pada orang, agresivitas, dan stabilitas dirasakan baik oleh seluruh responden. Budaya Organisasi yang baik akan menciptakan rasa nyaman bagi karyawan dalam melaksanakan tugas yang diberikan

2. Mutu Pelayanan Pegawai pada Pada Pusat Pengembangan dan Pemberdayaan Pendidik dan Tenaga Kependidikan (PPPPTK) Bisnis dan Pariwisata berdasarkan hasil penelitian dapat disimpulkan bahwa Mutu Pelayanan Pada Pusat Pengembangan dan Pemberdayaan Pendidik dan Tenaga Kependidikan (PPPPTK) 
Bisnis dan Pariwisata sudah dilaksanakan dengan baik. Karyawan Pada Pusat Pengembangan dan Pemberdayaan Pendidik dan Tenaga Kependidikan (PPPPTK) Bisnis dan Pariwisata memiliki rasa tanggung jawab yang tinggi dan dapat bekerja sama antar sesama karyawan sehingga menghasilkan prestasi kerja yang baik.

3. Pengaruh Budaya Organisasi terhadap Mutu Pelayanan.

Dari analisis yang telah peneliti lakukan mengenai pengaruh budaya organisasi terhadap mutu pelayanan dapat disimpulkan sebagai berikut:

Dari analisis korelasi $\left(\mathrm{r}_{\mathrm{xy}}\right)$ didapat korelasi antara budaya organisasi Pada Pusat Pengembangan dan Pemberdayaan Pendidik dan Tenaga Kependidikan (PPPPTK) Bisnis dan Pariwisata dengan mutu pelayanan sebesar 0,716. Dari analisis koefisien determinasi didapat hasil 51,265\%. Nilai $t_{\text {hitung }}>t_{\text {tabel }}(8,58>$ 2,00), maka dapat disimpulkan bahwa $\mathrm{H}_{\mathrm{o}}$ yang menyatakan tidak ada pengaruh antara budaya organisasi terhadap mutu pelayanan ditolak., sehingga $\mathrm{H}_{a}$ diterima. Budaya Organisasi pada Pusat Pengembangan dan Pemberdayaan Pendidik dan Tenaga Kependidikan (PPPPTK) Bisnis dan Pariwisata semakin baik maka semakin meningkat mutu pelayanan dan dari hasil uji signifikan hipotesis ada pengaruh antara budaya organisasi Pusat Pengembangan dan Pemberdayaan Pendidik dan Tenaga Kependidikan (PPPPTK) Bisnis dan Pariwisata terhadap mutu pelayanan.

\section{DAFTAR PUSTAKA}

Aedi, Nur, Manajemen, Bandung: Alpabeta, 2010.

Chatab, Nevizond , Profil Budaya Organisasi, Bandung: Alfabeta, 2007.

Gary, dessler, Manajemen Personalia, (terjemahan oleh Masud) Edisi ke enam, Jakarta: Erlangga, 2000.

Hendayat Soetopo, Perilaku Organisasi Teori dan Praktik, Bandung: Remaja Rosdakarya, 2010.

Malayu P. Hasibuan, Manajemen Sumber Daya Manusia, Jakarta: Masagung, Edisi ke-6, 2009.

Mangkunegara, Anwar Prabu, Manajemen Sumber Daya Manusia Perusahaan, 
Bandung: Remaja Rosdakarya, 2008.

Munandar, Ashar Sunyoto, Psikologi Industri dan Organisasi, Jakarta: UI-Press, 2004.

Nasution, M.N., Manajemen Mutu Terpadu, Jakarta: Ghalia Indonesia, 2004.

Hasibuan, H. M. S. P, “Manajemen SDM", Edisi Revisi Jakarta; PT. Bumi Aksara, 2005.

Siagian, Sondang. Manajemen Sumber Daya Manusia, Cetakan Kesembilan, Penebit PT. Bumi Aksara, Jakarta, 2002.

Ridwan, Skala Pengukuran Variabel-Variabel Penelitian, Bandung: Alfabeta, 2004.

Rivai, Veithzal, Manajemen Sumber Daya Manusia untuk Perusahaan dari Teori dan Praktek, Jakarta: RajaGrafindo Persada, 2009.

Samsudin, Sadili, Manajemen Sumber Daya Manusia, Bandung: Pustaka Setia, 2006.

Sedarmayanti, Sumber Daya Manusia dan Produktivitas Kerja, Bandung: Mandar Maju, 2004.

Simamora, Henry, Manajemen Sumber Daya Manusia, Yogyakarta: STIE YKPN, 2006

Sudarmanto, Kinerja dan Pengembangan Kompetensi SDM Teori, Dimensi Pengukuran dan Implementasi dalam Organisasi, Yogyakarta: Pustaka Pelajar, 2009.

Sugiyono, Statistik untuk Penelitian, Bandung, Alfabeta, 2006.

Sule, Ernie Tisnawati, Pengantar Manajemen, Jakarta: Prenada Media Group, 2010.

Suwarto, Budaya Organisasi, Universitas Atmajaya, 2009, Yogyakarta.

Tjiptono, Fandy dan Diana, Anastasi Quality Management, Yogyakarta: Andi, 2004

Umam, Khaerul, Perilaku Organisasi, Bandung: Pustaka Setia, 2010. Wibowo, Budaya Organisasi. Jakarta: PT. Raja Grafindo Persada, 2010 
